\title{
A Dynamic Perspective On Determinants Of Short-Term Debt Financing: Evidence From South African Listed Firms
}

Farai Kwenda, University of KwaZulu-Natal, South Africa Merle Holden, University of KwaZulu-Natal, South Africa

\begin{abstract}
This study analyses the determinants of short-term debt financing using the generalised method of moment (GMM) of estimation to attest whether it follows a partial adjustment process. The study analyses data collected for 92 firms listed on the JSE Securities Exchange (JSE) for the period 2001 to 2010. The evidence obtained from the study suggests that firms have a target level of short-term debt and follow an adjustment process towards the target level. Spontaneous and internal resources, investment opportunities and the state of the economy play an important role in the use of short-term debt as a short-term financing instrument among the listed companies. The study recommends that managers pay particular attention to the key factors that drive the use of short-term debt because of its importance in financing working capital.
\end{abstract}

Keywords: Substitute; Dynamic Panel; Financing; Short-Term Debt

\section{INTRODUCTION}

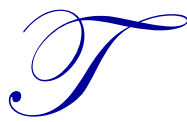

he success or failure of any business enterprise depends largely on its ability to make sound financial management decisions. These decisions can be discussed under three categories: capital budgeting, capital structure and working capital management. Working capital management decisions involve decisions about the financing and composition of current assets and this determines the liquidity position of the firm. These decisions present major challenge for finance managers because of the rapidly changing nature of short-term markets, the level of competition, inflation, cost of capital and pressure to deliver maximum shareholder value (Lamberson, 1995; Salawu, 2007). The recent global financial crisis, economic recession and the credit crunch make the financing of working capital a very important area of working capital management. The crisis rocked financial markets, negatively impacting on a firm's ability to access funds as more stringent measures were applied by banks to borrowers. The crisis served to emphasize the importance of access to short-term financing. For example, in 2008 three United States automobile manufacturers, Chrysler, Ford Motors, and General Motors, had to request a bail out from the government to finance running day-to-day expenses to save them from collapse. Their collapse would have resulted in almost 350000 direct job losses and approximately four-and-a-half million indirect job losses (Healey, C, \& Woodyard, 2008). Such cases serve to highlight that corporate failure has ripple effects; hence the need to attend to the subject of working capital financing as an important area of financial management.

South Africa has one of the most advanced financial systems in the world, which compares favourably to the financial systems of more developed economies (Skerritt, 2009). The South African banking sector, for example, though oligopolistic in nature (because it is dominated by the big four banks: ABSA, First Rand, Nedbank and Standard), ranks among the world's top ten. The regulatory framework, the depth of financial infrastructure and markets and the vitality of the banking system serve as proof of the advanced nature of the South African financial sector. Since 1996, bank credit to the private sector (BCPS) has consistently exceeded the country's GDP, which shows the importance of the banking sector to the private sector in South Africa. Despite this amount of BCPS, there seems to be heavy dependence on trade credit by big companies in South Africa. Table 1 shows that among the sample firms during the period under review, short-term debt and trade credit to current liabilities were 19\% and 
$70 \%$, respectively. In addition, while trade credit financed half of the current assets held by these firms, short-term debt financed less than a fifth. According to Fisman and Love (2003), supplier credit is an alternative for firms operating in underdeveloped financial markets.

Table 1 shows that firms marginally increased their use of short-term debt as a source of finance during the economic slowdown periods 2003-2004 and 2007-2009, and reduced their use of the same when the economy was doing well. The South African financial sector was somehow insulated from the global financial crisis and this has been attributed to the implementation of the National Credit Act (NCA) in 2007. These statistics leave one asking questions such as, what determines the use of short-term debt financing among listed firms in South Africa, and, what was the impact of the financial crisis on short-term debt used by big firms?

The study contributes to the body of knowledge by providing evidence on whether short-term debt follows the partial adjustment like trade credit (García-Teruel \& Martínez-Solano, 2010) and debt ratio (Ozkan, 2001). Our second contribution is an analysis of the impact of the global financial crisis on the short-term debt used by firms listed on the JSE. To the best of our knowledge, no study of this nature has been conducted.

\section{LITERATURE REVIEW}

According to Modigliani and Miller (1958), under perfect capital markets a firm's investment decisions are independent of its financial situation. In the absence of capital rationing, external financing can be accessed without difficulties, and a firm's expected future profitability should drive investment. However, modern financial and economic theories agree that real investment may be influenced by financial factors.

The matching principle in finance states that current assets, which are mainly made up of cash and nearcash items, inventory, receivables and prepayments, should be financed by current liabilities, which comprise shortterm debt, accruals and accounts payable. Non-current assets or fixed assets (plant, equipment, machinery, land and buildings) should be financed by long-term loans, debentures and equity. The matching of assets and liabilities maturity ensures that a firm avoids frequent refinancing and maturing obligations are met from cash flows generated by the business (Firer, Ross, Westerfield, \& Jordan, 2012). The matching principle means that the firm avoids using external funds thereby minimizing the agency problems between the interests of equity holders and debt providers (Myers, 1977).

\subsection{Sources of Working Capital Financing}

The two main sources of short-term funds are spontaneously generated sources such as accounts payable, provisions and accruals, and non-spontaneously generated sources such as unsecured and secured short-term borrowings and off-balance sheet financing instruments. Marx, de Swardt, Beaumont Smith, and Erasmus (2011, p. 188) state that spontaneous sources of financing arise from the ordinary course of business, are directly related to the sales level, and increase or decrease in direct proportion to sales. Secured short-term borrowings are usually made up of short-term bank loans, cash credit overdraft, and working capital demand loans. Unsecured financing (also known as financial statements lending) is short-term financing obtained from the money market without pledging any specific assets as collateral, and include negotiable certificates of deposit (NCD), commercial paper and banker's acceptances (BAs). BAs, however, are no longer active on the South African money market.

The most common term structure of interest rates is upward sloping, which means that long-term debt attracts higher interest rates than short-term debt (Firer et al., 2012). Firms may finance their long-term assets requirements with short-term debt in order to take advantage of lower interest rates. However, this exposes the firm to refinancing risk. Refinancing risk is made up of default risk and interest rate risk. Default risk arises when lenders, for whatever reason, decide not to renew the firm's debt contract and the firm has insufficient capital to redeem such debt. Interest rate risk is the risk that the firm's interest expense might rise due to refinanced debt attracting a higher interest rate. While short-term debt could be preferred to long-term debt because of its lower cost, it is more risky since short-term interest rates tend to be more volatile than long-term interest rates (see Appendix B for long-term and short-term interest rates in South Africa between 1970 and 2010). Heavy usage of short-term debt exposes the firm to bankruptcy risk because an inability to repay may hinder the firm's access to more funding, thereby forcing the firm into bankruptcy (Fosberg, 2012). 


\subsection{Bank Credit and Trade Credit}

There is no distinct evidence that trade credit and bank credit are substitutes or complements (Love, 2011). Theoretical papers such as Biais and Gollier (1997) and Giannetti, Burkart, and Ellingsen (2008) argue that these two are complements because trade credit conveys information to lenders, and firms that use trade credit borrow at favourable conditions from banks. However, trade credit compensates for the unavailability of bank credit particularly for firms operating in poorly developed financial markets. Fisman and Love (2003) argue that trade credit is a substitute for bank credit. Alphonse, Ducret, and Séverin (2006) provide evidence that trade credit conveys a message about a firm's quality and thus facilitates access to bank credit.

\subsection{Changes in Short Term Financing}

The level of short-term debt financing changes due to either the size effect or the substitution effect (Fosberg, 2012). The size effect is premised on the matching principle that states that short-term assets should equal short-term liabilities. The growth in current assets can be financed by spontaneous sources of finance. However, the spontaneous sources may be insufficient to cover all the growth in current assets; hence the need for additional short-term funds to support current assets growth. When current assets equal current liabilities, it means the current ratio is 1, which means that the firm has a Rand/Dollar in current assets to pay off every Rand/Dollar in current liabilities. However, as a risk management technique, firms tend to maintain a current ratio higher than 1 requiring more funding, and this portion is met using long-term funds.

The substitution effect implies that there is an inverse relationship between spontaneously-generated resources and short-term debt financing. Holding current assets constant, an increase in the firm's spontaneouslygenerated resources reduces the firm's need for short-term debt financing. Spontaneous sources of finance include accounts payable/trade credit and accruals (tax liability and dividends declared but not yet paid). Conversely, a reduction in spontaneous sources of financing increases the need for more short-term debt.

\subsection{Other Factors Influencing the Use of Short-Term Debt Financing}

In a number of respects, short-term debt finance and long-term debt are similar. Consequently, factors that influence long-term debt financing such as creditworthiness, non-debt tax shields, access to capital markets, the size of the firm, the availability of internal resources, the availability of collateral, investment and growth opportunities should also influence short-term debt financing. Below is a discussion of these factors and development of the hypothesis.

\subsubsection{Firm Size}

The size of the firm has been used to distinguish financially and non-financially constrained firms. Thus size impacts on the ability of the firm to access finance (Carpenter, Fazzari, \& Petersen, 1994). Large firms are more diversified and use more debt in their financing structure because financial markets are more accessible to them compared to small firms and face friendly interest rates when borrowing (Ferri \& Jones, 1979; Titman \& Wessels, 1998). In this study, the natural logarithm of market capitalisation is used as a proxy for size and a positive relationship between size and short-term debt is hypothesised.

\subsubsection{Availability of Internal Resources}

According to the Pecking Order Theory (POT) developed by Myers (1984) and Myers and Majluf (1984), firms follow a hierarchical financing pattern. Firms prefer internal funds (retained earnings) to external funds and with respect to external funds firms prefer short-term debt to long-term debt and long-term debt is preferred to equity. Following the POT, as the firm generates more internal resources it uses less short-term debt. However, the availability of internal earnings influences the capacity to service debt. Profitable firms have better capacity to service their debt and therefore can use more leverage in their financing structure. Less profitable firms are likely to be less self-sufficient because they have low plough-back profits hence may have increased reliance on short-term debt finance to finance their activities and asset requirements. The availability of internal resources was measured by 
earnings before interest and tax (EBIT) scaled by total assets. As an alternative to trade credit, and based on previous studies between trade credit and internal resources, we expect EBIT to be inversely related to short-term debt.

\subsubsection{Non-Debt Tax Shields}

Non-debt tax shields, measured by depreciation and amortization, reduce the amount of debt financing that a firm employs because they reduce the expected interest tax shield the debt will generate. These serve as a substitute for interest expense, which is deductible in the calculation of the corporate tax and are negatively correlated to the amount of debt the firm uses in its capital structure. Following Titman and Wessels (1998) and Ozkan (2001), the study uses the annual depreciation expense to total assets as a proxy for non-debt tax shields and expects an inverse relationship between short-term debt finance and non-debt tax shields.

\subsubsection{Fixed Assets}

Tangible assets are used as collateral when borrowing; therefore, firms with more tangible assets can afford to borrow more using tangible assets. Hence a strong positive relationship is hypothesised.

\subsubsection{Sales Growth}

Firms that have recorded a good growth pattern in the past are better positioned to continue on the growth path (Scherr \& Hulburt, 2001). Growth in the level of sales creates financing pressures and is a major determinant of the demand for short-term finance. Firms with higher sales growth levels are likely to employ more short-term debt as spontaneous sources may not be sufficient to meet the new current asset requirements. The growth is calculated as follows:

sales growth rate $=\frac{\text { Sales }_{t}-\text { Sales }_{t-1}}{\text { Sales }_{t-1}}$

Sales growth can either be positive or negative; therefore, we develop variable Pgrowth and $\mathrm{Ngrowth}$ to represent positive and negative sales growth, respectively. Pgrowth and Ngrowth are expected to influence shortterm debt positively and negatively, respectively.

\subsubsection{Creditworthiness}

A firm's creditworthiness is a major determinant of the ability to access credit. Creditworthiness as measured by a firm's age, that is, the number of years since incorporation. Studies such as Niskanen and Niskanen (2006) and Baños-Caballero, García-Teruel, and Martínez-Solano (2010) found that there is a relationship between the age of a firm and its ability to access external finance. Older firms are expected be more creditworthy and therefore should access finance from both trade suppliers and financial markets with ease and under less rigorous conditions. The natural logarithm of a firm's age is used as a proxy for creditworthiness and is expected to be positively related to short-term debt.

\section{SAMPLE AND DATA SOURCES}

The data for our analysis was extracted from McGregor BFA Library, which provides financial statements and market capitalisation information for firms listed on the JSE. Our data were constructed in the following manner. Financial services firms and investment trusts were excluded because the nature of their short-term debt is different from the context of this empirical study. We dropped all firms with any missing observations during our study period, 2001 to 2010, in order to produce a balanced panel. As a result of this data-cleaning exercises, we had 92 firms (and 920 observations), which is almost $25 \%$ of the firms listed on the JSE Main Board.

\subsection{Short-Term Debt and Trade Credit Financing}

Table 1 compares the extent to which short-term debt and accounts payable are used to finance current assets and total assets and their contribution to current liabilities and total debt financing. On average short-term 
debt and trade credit financed $17 \%$ and $50 \%$ of the current assets. Overall, short-term debt financed less than a tenth and trade credit financed $30 \%$ of total assets held by these firms. The average proportion of trade credit to both current liabilities and total debt is approximately four times that of short-term debt. On the basis of these data, it can be said that supplier credit is the more dominant financing instrument and short-term debt plays a complementary rather than a substitution role. Without following a specific pattern, short-term debt fluctuates between 15\%-19\% in financing current assets and $8 \%-11 \%$ in financing total assets. The proportion of short-term debt to total debt follows a declining trend between 2003 and 2006, picking up in 2007 and then it declines throughout the remainder of the study. Between 2005 and 2009, the proportion of short-term debt to total current liabilities increased by five percentage points from $16 \%$ to $21 \%$.

Table 1: Short-Term Debt and Trade Credit as a Source of Financing and Contribution to Total Financing

\begin{tabular}{|l|c|c|c|c|c|c|c|c|}
\hline \multicolumn{1}{|c|}{ Year } & TCCA & STDCA & TCTA & STDTA & TCCL & STDCL & TCTD & STDTD \\
\hline 2001 & 0.5092 & 0.1725 & 0.3183 & 0.1004 & 0.6820 & 0.2019 & 0.5611 & 0.1570 \\
\hline 2002 & 0.5180 & 0.1538 & 0.3308 & 0.0877 & 0.6921 & 0.1850 & 0.5746 & 0.1415 \\
\hline 2003 & 0.5187 & 0.1933 & 0.3346 & 0.1083 & 0.6778 & 0.1960 & 0.5709 & 0.1800 \\
\hline 2004 & 0.5160 & 0.1629 & 0.3307 & 0.0848 & 0.6823 & 0.1767 & 0.5666 & 0.1474 \\
\hline 2005 & 0.5061 & 0.1535 & 0.3340 & 0.0793 & 0.6857 & 0.1633 & 0.5486 & 0.1322 \\
\hline 2006 & 0.5144 & 0.1640 & 0.3274 & 0.0859 & 0.6728 & 0.1761 & 0.5487 & 0.1313 \\
\hline 2007 & 0.5024 & 0.1706 & 0.3168 & 0.0973 & 0.6718 & 0.1905 & 0.5487 & 0.1601 \\
\hline 2008 & 0.4929 & 0.1738 & 0.3155 & 0.0958 & 0.6699 & 0.1996 & 0.5302 & 0.1523 \\
\hline 2009 & 0.4755 & 0.1667 & 0.3009 & 0.0885 & 0.6967 & 0.2052 & 0.5292 & 0.1464 \\
\hline 2010 & 0.4852 & 0.1479 & 0.3026 & 0.0763 & 0.7217 & 0.1836 & 0.5540 & 0.1324 \\
\hline Overall & 0.5038 & 0.1660 & 0.3212 & 0.0904 & 0.6856 & 0.1878 & 0.5554 & 0.1479 \\
\hline
\end{tabular}

Source: Own calculations using a balanced panel over the period 2001 to 2010. Data obtained from the McGregor BFA library. TCCA = Trade Credit $/$ Current Assets, STDCA = Short term debt $/$ Current Assets, TCTA = Trade credit to total assets, STDTA $=$ Short term debt $/$ total assets, STDCL $=$ Short term debt $/$ Current liabilities, TCCL $=$ Trade Credit $/$ Current Liabilities, TCTD $=$ Trade credit $/$ total debt, $\mathrm{STDTD}=$ Short term debt / Total debt

\subsection{Descriptive Statistics}

The descriptive statistics are presented in Table 2. The average current liabilities to total assets are $47 \%$ (median value is $43 \%$ ). On average spontaneous sources, given as current liabilities less short-term debt scaled to total assets, were 38\%. The average short-term debt total assets is $9 \%$ (median value is 6\%), which means short-term debt finances less than a tenth of total assets of the sample firms. The average accounts payable to total assets is $32 \%$ (median value is 29\%), which means for most firms in this study the median is closer to the mean. Accruals, another spontaneous source of short-term finance, have a mean of 5\% (median of 3\%). The respective averages of positive and negative sales growth are $26 \%$ and $-3.5 \%$. The average EBIT to total assets were $21 \%$ with a median value of $17 \%$. The respective averages of current assets to total assets and fixed assets to total assets were $64 \%$ and 28\%. On average the South African economy grew by 3.5\% between 2001 and 2010. All variables have median values less than the mean, which indicates a scattering towards the right of the tail suggesting that some companies' variables have values that are less than others.

The 10 per centile have an almost negligible amount of short-term debt and the 90 per centile finance $22 \%$ of their assets using short-term debt. When these per centiles are compared to the same per centiles, these figures are far below the 10 and 90 per centile of trade credit which are $13 \%$ and $61 \%$, respectively, which further suggests greater use of trade credit than short-term debt.

\section{METHODOLOGY}

The study uses a dynamic approach in analysing the determinants of short-term debt financing for a number of reasons. García-Teruel and Martínez-Solano (2010) found that firms have a target level of accounts payable and partially adjust towards their target level. Since short-term debt is considered as a complement or substitute to trade credit (by implication they may have similar properties), we test whether short-term debt also follows the same adjustment process. In a number of respects short-term debt shares the same characteristics as long-term debt. For example, though overdraft is classified as short-term debt and repayable on demand, it is a permanent feature on a firm's balance sheet and therefore qualifies to be treated the same way as long-term debt. Interest on both forms of 
debt is tax-deductible. Short-term debt, like long-term debt, can be used to finance permanent current assets if a firm decides to take advantage of lower interest rates. Estimating the level of sales and the current assets required to support the sales level is fraught with difficulties. Since current assets are supported by short-term financing, shortterm finance may not always be at the desired level.

The estimation model (see Appendix A for model specification) for the determinants of short-term debt STDTA $_{\text {it }}$ would be as follows:

$S T D T A=\beta_{0}+\beta_{1} S T D T A_{i t-1}+\beta_{2}$ OCLTA $_{i t}+\beta_{3}$ EBITTA $_{i t}+\beta_{4} L_{\text {LNMCAP }}+\beta_{5}$ PGROWTH $_{i t} \beta_{6}$ NGROWTH $_{i t}+$ $\beta_{7}$ NDTSTA $_{i t}+\beta_{8}$ FIXATA $_{i t}+\beta_{9} R G D P_{i t}+\beta_{10} R G D P_{i t}+\beta_{11} C A T A_{i t}+\eta_{i}+\lambda_{t}+\varepsilon_{I}$

where STDTA $\mathrm{A}_{\mathrm{it}-1}$ represents lagged short term debt to total assets, OCLTA $\mathrm{it}_{\mathrm{it}}$ represents spontaneous sources scaled to total assets, SIZE $_{\text {it }}$ is the size of the firm proxyed by natural log of the market capitalisation; CATA $_{i t}$ is investment in current assets, $\mathrm{NDTS}_{\mathrm{it}}$ is non-debt tax shield, EBITTA is earnings before interest and tax, $\mathrm{AGE}_{\mathrm{it}}$ is the number of years since incorporation, PGROWTH is positive sales growth, NGROWTH $_{\mathrm{It}}$ is negative sales growth and FIXATA $_{\mathrm{it}}$ is fixed assets to total assets. $\eta_{i}$ measures the unobservable individual effects include the nature of a firm's business or products, management's risk tolerance and entrepreneurial abilities. Such characteristics vary across firms but are assumed constant. $\lambda_{t}$ is introduced in the model in order to control for both observable and unobservable time effects that may affect the firm's short term borrowing decisions which the firm cannot control.

Table 2: Descriptive Statistics

\begin{tabular}{|c|c|c|c|c|c|c|}
\hline Variable & Definition & Mean & Std. Dev. & Median & Perc 10 & Perc 90 \\
\hline STDTA & Short - term debt/ total assets & 0.0904 & 0.1104 & 0.0596 & 0.0003 & .2190 \\
\hline CLTA & Current liabilities/ total assets & 0.4658 & 0.2199 & 0.4309 & 0.2090 & 0.7385 \\
\hline OCLTA & (Current liabilities - Short - term debt)/total assets & 0.3754 & 02535 & 0.3210 & 0.1539 & 0.6635 \\
\hline ACPTA & Accounts payable / total assets & 0.3212 & 0.1823 & 0.2862 & 0.1264 & 0.6074 \\
\hline ACCTA & Accruals/ total assets & 0.0542 & 0.0712 & 0.0348 & 0.046 & 0.1112 \\
\hline NTDSTA & Non - debt tax shields/ total assets & 0.0345 & 0.0244 & 0.03 & 0.0083 & 0.0623 \\
\hline EBITTA & Earnings before interest and tax / total assets & 0.2110 & 0.2037 & 0.1703 & 0.0581 & 0.4041 \\
\hline CATA & Current assets/ total assets & 0.6431 & 0.2230 & 0.6570 & 0.3312 & 0.9127 \\
\hline SKTA & Stock/ total assets & 0.2248 & 0.1434 & 0.2030 & 0.0511 & 0.4319 \\
\hline CMSTA & Cash and marketable securities / total assets & 0.1326 & 0.1175 & 0.109 & 0.0117 & 0.2864 \\
\hline TDTA & Trade debtors / total assets & 0.2937 & 0.1508 & 0.2764 & 0.1184 & 0.4902 \\
\hline LTDTA & Long term debt/ total assets & 0.1348 & 0.2065 & 0.0809 & 0.0074 & 0.3036 \\
\hline $\mathrm{P}_{\text {GROWTH }}$ & Positive sales growth & 0.2576 & 0.6071 & 0.13 & 0 & 0.5000 \\
\hline $\mathrm{N}_{\text {GROWTH }}$ & Negative sales growth & -0.0354 & 0.1454 & 0 & -0.1100 & 0 \\
\hline SIZE & Market capitalisation (000s) & 16000000 & 49600000 & 2150000 & 113000 & 28800000 \\
\hline AGE & Number of year since incorporation & 45 & 30 & 40 & 10 & 87 \\
\hline RGDP & Real Gross Domestic Product growth rate & 0.035 & 0.0066 & 0.0365 & & \\
\hline
\end{tabular}

Source: Own calculations using a balanced panel over the period 2001 to 2010. Data obtained from the McGregor BFA library.

\section{ESTIMATION RESULTS AND ANALYSIS}

\subsection{Regression Results}

Table 3 presents the estimation results our model carried out using the two-stage GMM estimator advanced by Arellano and Bond (1991). In all the six models, no second-order serial correlation as measured by the $\mathrm{m} 2$ was found in any test, which means our estimations are consistent. The test for the validity of the instruments using the Sargan test did not exhibit any problem.

The results obtained show that the lagged dependent variable is positive and precisely defined, except in Model 4 (where it is significant at 5\%). Therefore the dynamic approach used in this study is not rejected. Without time dummies, the speed of adjustment as measured by $1-\chi$, lies between 0.76 and 0.78 , which means that firms quickly adjust their levels of short-term debt. It might be because the cost of being in disequilibrium is so high that firms have to adjust quickly. The speed of adjustment might also be reflective of the nature of short-term debt; some loans are of a self-liquidating nature as it is paid off from maturing short-term current assets. In Model 3 we include 
time dummies but do not report them for brevity reasons, and the speed of adjustment in both models is 0.67, suggesting that the adjustment process is affected by time and changes with time. In Model 3 we also report the results of disaggregated current assets, that is stock, trade debtors and cash and cash equivalents, and find that there are no significant changes to the lagged dependent variable, which means that the speed of adjustment is not affected by the current asset structure of the firm.

\subsection{Spontaneous Resources}

Consistent with expectations, the coefficient of spontaneous sources of finance OCLTA is negative and statistically significant at $1 \%$ in Model 2 and at $5 \%$ in all the other models. This means that as spontaneously generated resources increase, firms employ less short-term debt. However, this finding contradicts the finding of Fosberg (2012) who found a positive and statistically significant relationship between spontaneous sources OCLTA and short-term debt. In Model 4 we present the results of the disaggregated spontaneous sources: trade credit and accruals. The coefficient of the lagged short-term debt is statistically significant at 5\% and both trade credit and accruals have negative statistical significance at $10 \%$, which confirms the substitute relationship between trade credit and spontaneous sources. The economic impact ${ }^{1}$ of OCLTA is very significant because a one increase in the standard deviation produces a decrease in the dependence variable of between $62 \%$ and $67 \%$.

\subsection{Current Assets}

The study finds that the positive relationship between CATA and short-term debt is statistically significant at $1 \%$ in Models 2 and 4, suggesting that firms in this study follow the matching principle. The relationship between STDTA and the three forms of current assets was also analysed in Model 3. Only inventory has a positive and statistically significant coefficient (at 10\%) which suggests that the increase in inventory is partly financed by shortterm debt. These results are consistent with Fosberg (2012), and the study did not find any evidence of any relationship between cash and marketable securities and short-term debt. An attempt was made to reconcile the positive relationship between short-term debt and CATA in this study with the finding of trade credit and CATA in previous studies. Since short-term debt is a considered a substitute/alternative or a complement to trade credit, it follows that the relationship between CATA and trade credit should be similar to the relationship between short-term debt and trade credit. A positive relationship was found between current assets and trade credit according to Niskanen and Niskanen (2006) and García-Teruel and Martínez-Solano (2010). Similarly, this study finds a positive relationship between $C A T A$ and short-term debt, which confirms the substitute or complementary role.

\footnotetext{
${ }^{1}$ The economic impact was calculated as the coefficient of a statistically significant independent variable multiplied by its standard deviation divided by the standard deviation of the dependent variable.
} 
Table 3: Determinants of Short-Term Debt Finance

\begin{tabular}{|c|c|c|c|c|c|c|}
\hline & $\begin{array}{c}(1) \\
\text { STDTA }\end{array}$ & $\begin{array}{c}(2) \\
\text { STDTA }\end{array}$ & $\begin{array}{c}\text { (3) } \\
\text { STDTA }\end{array}$ & $\begin{array}{c}(4) \\
\text { STDTA }\end{array}$ & $\begin{array}{c}(5) \\
\text { STDTA }\end{array}$ & $\begin{array}{c}(6) \\
\text { STDTA } \\
\end{array}$ \\
\hline STDTA $_{t-1}$ & $\begin{array}{c}0.244^{* * * *} \\
(2.98)\end{array}$ & $\begin{array}{c}0.325^{* * * *} \\
(3.13)\end{array}$ & $\begin{array}{c}0.225^{* * * *} \\
(2.72)\end{array}$ & $\begin{array}{c}0.219^{* * *} \\
(2.22)\end{array}$ & $\begin{array}{c}0.267 * * \\
(2.91)\end{array}$ & $\begin{array}{c}0.255^{* * * *} \\
(2.76)\end{array}$ \\
\hline OCLTA & $\begin{array}{c}-0.273^{* *} \\
(-2.57)\end{array}$ & $\begin{array}{c}-0.290^{* * * *} \\
(-2.94)\end{array}$ & $\begin{array}{c}-0.240^{* *} \\
(-2.08)\end{array}$ & $\begin{array}{l}- \\
-\end{array}$ & $\begin{array}{c}-0.260 * * \\
(-2.50)\end{array}$ & $\begin{array}{c}-0.269^{* *} \\
(-2.55)\end{array}$ \\
\hline EBITTA & $\begin{array}{c}-0.0726^{* * *} \\
(-2.57)\end{array}$ & $\begin{array}{c}-0.0889^{* * * *} \\
(-2.81)\end{array}$ & $\begin{array}{c}-0.0620^{* * *} \\
(-2.46)\end{array}$ & $\begin{array}{c}-0.0571^{* *} \\
(-2.13)\end{array}$ & $\begin{array}{c}-0.0782 * * \\
(-2.51)\end{array}$ & $\begin{array}{r}-0.0743^{\text {*** }} \\
(-2.20)\end{array}$ \\
\hline LNMCAP & $\begin{array}{c}-0.00418 \\
(-0.40)\end{array}$ & $\begin{array}{c}-0.00629 \\
(-0.44)\end{array}$ & $\begin{array}{c}-0.00911 \\
(-0.78)\end{array}$ & $\begin{array}{c}-0.00670 \\
(-0.54)\end{array}$ & $\begin{array}{c}0.000712 \\
(0.07)\end{array}$ & $\begin{array}{c}0.000200 \\
(0.01)\end{array}$ \\
\hline PGROWTH & $\begin{array}{c}0.0201^{* * * *} \\
(4.86)\end{array}$ & $\begin{array}{c}0.0163 \\
(1.69)\end{array}$ & $\begin{array}{c}0.0176^{* * * *} \\
(4.16)\end{array}$ & $\begin{array}{c}0.0205^{* * * *} \\
(5.53)\end{array}$ & $\begin{array}{c}0.0177 * * \\
(3.10)\end{array}$ & $\begin{array}{c}0.0174^{\text {**** }} \\
(2.95)\end{array}$ \\
\hline NGROWTH & $\begin{array}{c}-0.0178 \\
(-1.60)\end{array}$ & $\begin{array}{c}-0.0131 \\
(-0.78)\end{array}$ & $\begin{array}{c}-0.0126 \\
(-0.96)\end{array}$ & $\begin{array}{c}-0.0173 \\
(-1.56)\end{array}$ & $\begin{array}{c}-0.0160 \\
(-1.32)\end{array}$ & $\begin{array}{c}-0.0153 \\
(-1.25)\end{array}$ \\
\hline LNAGE & $\begin{array}{c}-0.0140 \\
(-0.44)\end{array}$ & $\begin{array}{c}0.00558 \\
(0.27)\end{array}$ & $\begin{array}{c}0.00317 \\
(0.14)\end{array}$ & $\begin{array}{c}0.00230 \\
(0.08)\end{array}$ & $\begin{array}{c}-0.0163 \\
(-0.49)\end{array}$ & $\begin{array}{c}-0.0166 \\
(-0.48)\end{array}$ \\
\hline FIXATA & $\begin{array}{c}0.0460 \\
(0.58)\end{array}$ & $\begin{array}{c}0.0184 \\
(0.23)\end{array}$ & $\begin{array}{c}-0.0707 \\
(-0.75)\end{array}$ & $\begin{array}{c}0.0558 \\
(0.69)\end{array}$ & $\begin{array}{c}0.0652 \\
(0.76)\end{array}$ & $\begin{array}{c}0.0680 \\
(0.75)\end{array}$ \\
\hline NDTSTA & $\begin{array}{c}0.0250 \\
(0.05)\end{array}$ & $\begin{array}{l}0.129 \\
(0.24)\end{array}$ & $\begin{array}{l}-0.175 \\
(-0.32)\end{array}$ & $\begin{array}{l}-0.155 \\
(-0.30)\end{array}$ & $\begin{array}{c}-0.0032 \\
(-0.01)\end{array}$ & $\begin{array}{l}0.151 \\
(0.31)\end{array}$ \\
\hline RGDP & $\begin{array}{c}0.424^{* * *} \\
(2.58)\end{array}$ & - & $\begin{array}{l}0.148 \\
(1.34)\end{array}$ & $\begin{array}{c}0.231 * * \\
(1.96)\end{array}$ & - & - \\
\hline CRISIS & $\begin{array}{c}0.0170^{* *} \\
(2.31)\end{array}$ & $\begin{array}{l}- \\
-\end{array}$ & - & - & $\begin{array}{l}- \\
-\end{array}$ & $\begin{array}{l}- \\
-\end{array}$ \\
\hline TERM STR & $\begin{array}{l}- \\
-\end{array}$ & - & $\begin{array}{l}- \\
-\end{array}$ & $\begin{array}{l}- \\
-\end{array}$ & $\begin{array}{l}- \\
-\end{array}$ & $\begin{array}{c}-0.0033 * \\
(-1.92)\end{array}$ \\
\hline CATA & $\begin{array}{c}0.191^{* *} \\
(2.54)\end{array}$ & $\begin{array}{c}0.187^{* * * *} \\
(2.65)\end{array}$ & $\begin{array}{l}- \\
-\end{array}$ & $\begin{array}{c}0.199^{* * *} \\
(2.78)\end{array}$ & $\begin{array}{c}0.185 * * \\
(2.22)\end{array}$ & $\begin{array}{c}0.203^{* * *} \\
(2.53)\end{array}$ \\
\hline SKTA & - & $\begin{array}{l}- \\
-\end{array}$ & $\begin{array}{c}0.0483 * \\
(1.74)\end{array}$ & $\begin{array}{l}- \\
-\end{array}$ & $\begin{array}{l}- \\
-\end{array}$ & - \\
\hline TDTA & - & $\begin{array}{l}- \\
-\end{array}$ & $\begin{array}{c}0.0694 \\
(0.71)\end{array}$ & - & $\begin{array}{l}- \\
-\end{array}$ & - \\
\hline CMSTA & $\begin{array}{l}- \\
-\end{array}$ & $\begin{array}{l}- \\
-\end{array}$ & $\begin{array}{c}0.0130 \\
(0.21)\end{array}$ & - & $\begin{array}{l}- \\
-\end{array}$ & - \\
\hline TCTA & - & - & - & $\begin{array}{c}-0.218 * \\
(-1.88)\end{array}$ & - & - \\
\hline ACCTA & - & $\begin{array}{l}- \\
-\end{array}$ & $\begin{array}{l}- \\
-\end{array}$ & $\begin{array}{c}-0.378^{*} \\
(-1.71)\end{array}$ & $\begin{array}{l}- \\
-\end{array}$ & $\begin{array}{l}- \\
-\end{array}$ \\
\hline CONS & $\begin{array}{l}0.151 \\
(0.60)\end{array}$ & $\begin{array}{l}0.156 \\
(0.49)\end{array}$ & $\begin{array}{l}0.330 \\
(1.19)\end{array}$ & $\begin{array}{l}0.144 \\
(0.51)\end{array}$ & $\begin{array}{l}0.0681 \\
(0.30)\end{array}$ & $\begin{array}{l}0.0663 \\
(0.22)\end{array}$ \\
\hline $\begin{array}{l}\text { Time dummies } \\
\mathrm{m}_{2}\end{array}$ & $\begin{array}{c}- \\
0.5883\end{array}$ & $\begin{array}{c}\text { Yes } \\
0.3199\end{array}$ & 0.671 & 0.9478 & $\begin{array}{c}- \\
0.5011\end{array}$ & 0.5162 \\
\hline $\begin{array}{l}\text { Sargan test } \\
\text { p-values }\end{array}$ & $\begin{array}{c}21.97(20) \\
0.3422\end{array}$ & $\begin{array}{c}29.92(20) \\
0.0712\end{array}$ & $\begin{array}{c}22.76(20) \\
0.3008\end{array}$ & $\begin{array}{c}26.03(20) \\
0.1649\end{array}$ & $\begin{array}{c}24.16(20) \\
0.2355\end{array}$ & $\begin{array}{c}25.86(20) \\
0.1703\end{array}$ \\
\hline$N$ & 736 & 736 & 736 & 736 & 736 & 736 \\
\hline
\end{tabular}

Source: Own calculations using a balanced panel over the period 2001 to 2010. Data obtained from the McGregor BFA library. $t$ statistics in parentheses $* * *$ and $* * *$ significant at $10 \%, 5 \%$ and $1 \%$ respectively.

Generally short-term debt is either unsecured or secured against liquid assets; therefore the positive relationship can also have a different interpretation. The positive coefficients could also be a result of the use of current assets as collateral against short-term borrowing. If short-term funds providers require collateral, an increase in current assets results in more capacity to borrow more short-term funds ceteris paribus; hence a positive association.

\subsection{Sales Growth}

Positive sales growth follows the expected sign, meaning that positive sales growth results in an increase in the amount of short-term borrowings. The level of current assets increases in tandem with an increase in the level of 
sales in order to produce at a higher level; hence the sales growth increases the need for short-term funds. This finding is similar to the findings of Khan, Tragar, and Bhutto (2012) on the impact of sales growth on trade credit, confirming the substitution relationship hypothesised. A one increase in the standard deviation of PGROWTH produces an average increase in short term debt of $11 \%$ which shows the strong economic impact of positive sales growth assets on short term debt. Conversely, negative growth sales reduce the need for short-term funds. The study does not find any evidence that negative sales growth has any influence on short-term debt. Probably this negative sales growth impacts negatively on the credit rating of a firm, hence it has no significant impact on the short-term debt of the firm.

\subsection{Operating Cash Flows and State of the Economy}

The coefficient of EBITTA is negative and statistically significant at $5 \%$ in most of the models, confirming the inverse relationship with short-term debt. An increase in operating cash flows reduces the need for external finance needed to support the growth in current assets. In this respect, short-term debt follows the same characteristics as trade credit and is consistent with the Pecking Order Theory of capital structure (García-Teruel \& Martínez-Solano, 2010; Niskanen \& Niskanen, 2006; Petersen \& Rajan, 1997) and debt ratio (Ozkan, 2001). The economic impact of EBITTA is very significant. A one increase one standard deviation in the variable EBITTA, STDTA, (the dependent variable) decreases by $13 \%$ on average. Good performance in the economy impacts positively on the short-term debt levels used by firms, as RGDP is statistically significant at $1 \%$. When the economy is in an expansion phase, firms are likely to experience higher rates of stock turnover and growth in current assets, which increase the need for funding to support this growth.

\subsection{Term Structure}

Interest on corporate debt is tax deductible and this creates an interest tax shield which enhances the value of the firm. An upward sloping term structure encourages the use of short term debt while a downward sloping encourages the use of long term debt (Gitman et al., 2010). Term structure was calculated as the difference between the 10-year South African bond yield and three-month South Africa government Treasury bills yield. The study found a statistically significant negative relationship between short term debt and term structure, consistent with the analysis of Brick and Ravid (1991). Brick and Ravid (1991) argue that firms employ less short term bank borrowing when the term structure is upward sloping and vice versa. This is consistent with the tax liability argument which states that an upward sloping yield curve favours the use of long term debt in order to benefit from a higher the tax shield generated by a higher tax liability (thereby increasing the value of the firm).

\subsection{The Global Financial Crisis}

In Model 1 we include the dummy variable CRISIS which took the form 1 (and 0 otherwise) to represent the period of the financial crisis of 2008 and 2009. The dummy variable's coefficient is positive and statistically significant at 5\%, suggesting that the global financial crisis had a positive impact on short-term debt levels used by these listed firms in South Africa. This result lends support to the trend analysis reported in Table 1 that shows that the level of short-term debt marginally increased in the period 2008-2009. This result also lends support to the notion that South African banks were not affected by the crisis, thanks to the implementation of the NCA prior to the crisis, and probably were still able to extend more credit during the crisis period. It also suggests that firms resorted to more bank finance even though interest rates were high, which emphasizes the fact that in times of a credit crunch, access to credit preponderate the cost of credit. Consequently, firms borrow even at high interest rate in order to keep the operations running. South African firms have conservative capital structures and low debt levels (Erasmus, 2009); therefore it is possible that these firms were able to increase their debt levels during the time of the crisis.

\subsection{Other Independent Variables}

The study did not find any influence of size, non-debt tax shields, creditworthiness and fixed assets on the level of short-term debt used by these firms. Most short-term borrowing is either unsecured or secured against current assets or liquid assets and this probably explains the non-significance of fixed assets. 


\subsection{Robustness of Results}

Several tests were done to check the robustness of the findings of the study. Although we do not report them for brevity reasons, we conducted estimations using alternative proxies to firm size (the natural logarithm of sales and the natural logarithm of total assets). We also used other proxies for growth opportunities (the Q ratio and the market-to-book ratio). The findings obtained using these alternative proxies were either similar to our main models or there were no significant changes to the signs of the explanatory variables as a result of changing one variable. In addition, both tests for auto-correlation and the validity of instruments did not show any problem as a result of changes in the proxies.

\section{CONCLUSION}

The major aims of the study were to establish that short-term debt follows an adjustment process like trade credit and debt ratio, and to examine factors influencing its use by South African listed firms. The study provides evidence that factors that influence trade credit also influence short-term debt; corroborating the argument that trade credit is an alternative financing instrument to short-term debt. Firms have target short-term debt levels and the adjustment towards the target level is relatively fast as shown by coefficients that ranged between 0.67 and 0.78 . The study found that factors influence trade credit as a short-term financing; internal resources, sales growth and current asset structure also influence the use of short-term debt. No evidence was found to support the argument that size, creditworthiness, non-debt tax shields and fixed assets explain a firm's use of short-term debt as a source of funds.

The study established that trade credit and short term financial debt share factors that influence their use. Further research should be done on when both trade credit and short term debt are available, which financing instrument do firms chose between the two.

\section{AUTHOR INFORMATION}

Farai Kwenda, is a lecturer and $\mathrm{PhD}$ candidate in the School Accounting, Economic and Finance with research interests in corporate finance and micro finance. E-mail: kwendaf@ukzn.ac.za (Corresponding author)

Merle Holden, Professor Merle Holden is Emeritus Professor in the School of Accounting, Economics and Finance at the University of KwaZulu-Natal, Durban. After graduating from the University of Natal with an Honours degree, she completed her graduate study in the US and holds a Ph.D. in Economics from Duke University. She was Associate Professor of Economics at George Mason University in Virginia, US, before returning to South Africa in 1982 to the University of Natal. She served as Head of the School of Economics and Management and Dean of the Faculty at the University of Natal. She has been a part time member of the Competition Tribunal of South Africa since 1999. E-mail: merleholden@gmail.com

\section{REFERENCES}

1. Alphonse, P., Ducret, J., \& Séverin, E. (2006). When trade credit facilitates access to bank finance: Evidence from US small business data.

2. Arellano, M., \& Bond, S.R. (1991). Some tests of specification for panel data Monte Carlo evidence and an application to employment equations. Review of Economic Studies, 58, 277-297.

3. Baños-Caballero, S., García-Teruel, P., \& Martínez-Solano, P. A. (2010). Working capital management in SMEs,. Accounting and Finance, 50, 511-527.

4. Biais, B., \& Gollier, C. (1997). Trade credit and credit rationing. The Review of Financial Studies, 10(4), 903-937.

5. Brick, I. E., \& Ravid, S. A. (1991). Interest rate uncertainty and the optimal debt maturity structure. Journal of Financial and Quantitative Analysis, 29, 63-81.

6. Carpenter, R. E., Fazzari, S. M., \& Petersen, B. C. (1994). Inventory investment, internal finance fluctuations and business cycle Brooking Papers Economic Activity, 25, 75-138.

7. Erasmus, P. (2009). Capital structure and debt maturity choices for South African firms: Evidence from a highly variable economic environment. 
8. Ferri, M. G., \& Jones, W. H. (1979). Determinants of financial structure: A new methodologicial approach. Journal of Finance, 34, 631-644.

9. Firer, C., Ross, S. A., Westerfield, R. W., \& Jordan, B. D. (2012). Fundamentals of corporate finance (5th South African ed.). Berkshire McGraw-Hill Education.

10. Fisman, L., \& Love, I. (2003). Trade credit, financial intermediary development, and industry growth. Journal of Finance, 58, 353-374.

11. Fosberg, R. H. (2012). Determinants of short-term debt financing. Research in Business and Economics Journal, 6(July), 1-11.

12. García-Teruel, P., \& Martínez-Solano, P. A. (2010). A dynamic perspective on the determinants of accounts payable. Review of Quantitative Finance and Accounting, 34, 439-457.

13. Giannetti, M., Burkart, M., \& Ellingsen, T. (2008). What you sell is what you lend? Explaining trade credit contracts. The Review of Financial Studies.

14. Gitman, L. J., Beaumont Smith, M., Hall, J., B., Lowies., Marx. J., Strydom, B., \& van der Merwe, A. (2010). Principles of Managerial Finance: Global and South African Perspectives (1st ed.). Cape Town: Pearson Education South Africa.

15. Healey, J. R., C, Sharon. S., \& Woodyard, C. (2008, 22/04/2013). \$15B could help automakers now, but what about later? USA Today.

16. Khan, M. A., Tragar, G. A., \& Bhutto, N. A. (2012). Determinants of accounts receivable and accounts payable: A case of Pakistan textile sector. Interdisciplinary Journal of Contemporary Research In Business, 3(9), 240-251.

17. Lamberson, M. (1995). Changes in working capital of small firms in relation to changes in economic activity. Mid-American Journal of Business, 10(2), 45-50.

18. Love, I. (2011). Trade credit and bank credit: Evidence from recent financial crises. In J. Chauffour \& M. Malouche (Eds.), Trade finance during the great trade collapse (pp. 27-39). Washington D.C: World Bank Publications.

19. Marx, J., de Swardt, C., Beaumont Smith, M., \& Erasmus, P. (2011). Financial management in Southern Africa (3rd ed.). Cape Town Pearson Education South Africa.

20. Myers, S. C. (1977). Determinants of corporate borrowings. Journal of Financial Economics, 5, 147-175.

21. Niskanen, J., \& Niskanen, M. (2006). The determinants of corporate trade credit polices in a bankdominated financial environment: The case of Finnish small firms. European Financial Management, 12, 81-102.

22. Ozkan, A (2001). Determinants of capital structure and adjustment to long run target: Evidence from UK company panel data. Journal of Business Finance and Accounting, 28(1), 175-198.

23. Petersen, M. A., \& Rajan, R. G. (1997). Trade credit: theories and evidence. Review of Financial Studies, 10(3), 661-691.

24. Salawu, R. O. (2007). Capital industry practice and aggressive conservative working capital policies in Nigeria. Global Journal Of Business Research, 1(2), 109-117.

25. Scherr, F. C., \& Hulburt, H. M. (2001). The debt maturity structure of small firms. Financial Management, 30, 85-111.

26. Skerritt, P. (2009). The financial landscape. In Z. B. C. Van Zyl, P. Skerritt \& I. Goodspeed (Ed.), Understanding the South African financial markets (3rd ed.). Pretoria: Van Schaik Publishers.

27. Titman, S., \& Wessels, R. (1998). The determinants of capital structure choice. Journal of Finance, 43, 119. 


\section{APPENDIX A}

\section{Model Specification}

The target short-term debt level $\left(s t d_{i t}^{*}\right)$ is estimated as follows:

$s t d_{i t}^{*}=\alpha+\sum_{k} \rho_{k} \Upsilon_{k i t}+\varepsilon_{i t}$

where $s t d$ is short-term debt; firms are represented by subscript $I=1, \ldots, N$; time, $t=1, \ldots T ; X_{i t}$ is a $K x 1$ vector of explanatory variables; $\rho_{k}$ is a vector of the financial and operating parameters to estimated and $\varepsilon_{i t}$ the random disturbance.

Firms adjust their level of short-term debt according to the degree of adjustment $\chi$ in order for their current level to be close to their desired level:

$s t d_{i, t}-s t d_{i, t-1}=\chi\left(s t d_{i, t}^{*}-s t d_{i, t-1}\right)$

$0 \leq \chi \leq 1$

The expression $s t d_{i, t}-s t d_{i, t-1}$ is the adjustment required to reach the firm's target short-term debt level. The coefficient $\chi$ measures the adjustment speed or the capacity of the firm to reach its desired short-term debt level. The coefficient $\chi$ is inversely related to the adjustment costs and takes values between 0 and 1 . If $\chi$ is 0 , it shows that firms face high adjustments costs such that the current level of short-term debt remains as in the previous period. On the contrary, if $\chi$ is 1 , it indicates that firms quickly adjust from the current level to the desired level.

Rearranging equation A2:

$s t d_{i, t}=\chi s t d_{i, t}^{*}-\chi s t d_{i, t-1}+s t d_{i, t-1}$

$0 \leq \chi \leq 1$

$s t d_{i, t}=(1-\chi) s t d_{i, t-1}+\chi s t d_{i, t}^{*}$

$0 \leq \chi \leq 1$

$$
\text { If }(1-\chi)=\partial_{0} \text { and } \chi=\partial_{1} \text { then: }
$$

$s t d_{i, t}=\partial_{0} s t d_{i, t-1}+\partial_{1}\left[\alpha+\sum_{k} \rho_{k} \Upsilon_{k i t}+\varepsilon_{i t}\right]$

which can be expressed as:

$s t d_{i, t}=\pi+\beta_{0} s t d_{i t-1}+\sum_{k=1} \beta_{k} Y_{k i t}+\mu_{i t}$

where $\pi=\alpha \partial ; \beta_{0}=\partial_{0}=(1-\chi) ; \beta_{k}=\chi \rho_{k}=\partial_{1} \rho_{k}$ and $\mu_{i t}=\chi \varepsilon_{k i t}\left(\right.$ where $\chi \varepsilon_{k i t}$ has the same properties as $\left.\mu_{i t}\right)$. 


\section{APPENDIX B}

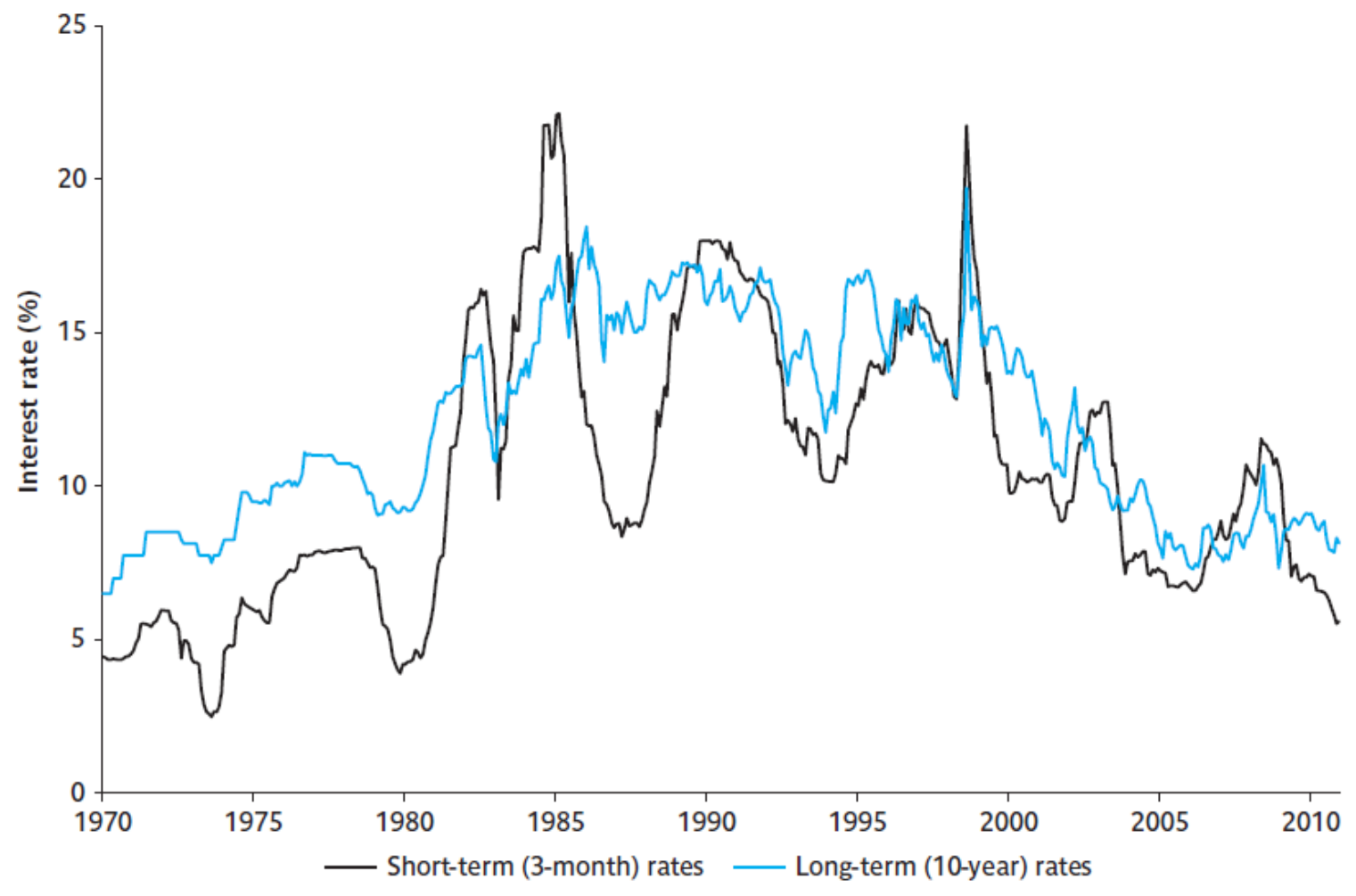

South African Interest Rates 1970-2010

Source: Firer, C., Ross, A.S., Westerfield, R.W., \& Jordan, B.D. (2012). Fundamentals of Corporate

Finance ( $4^{\text {th }}$ South African ed.). McGraw-Hill Berkshire (p. 205) 
NOTES 